\title{
MAJOR BIOACTIVE TRITERPENOIDS FROM GANODERMA SPECIES AND THEIR THERAPEUTIC ACTIVITY: A REVIEW
}

\author{
ZAHOOR AHMAD BHAT*, ABDUL HAMID WANI, MOHD YAQUB BHAT, ABDUL RASHID MALIK \\ Department of Botany, Section of Plant Pathology and Mycology, University of Kashmir, Hazaratbal, Srinagar, India. \\ Email: zahoorbht20@gmail.com
}

Received: 29 January 2019, Revised and Accepted: 13 March 2019

\begin{abstract}
Ganoderma a traditional Chinese medicine popularly used for complementary cancer therapy and longevity for centuries. The vast amount of study has been performed on the medicinal properties of Ganoderma lucidum. G. lucidum contains various compounds with a high grade of biological activity, which increase the immunity. Several of these substances belong to the triterpenoids and polysaccharides. Proteins, sterols, phenols, lipids, etc., are also present. Ganoderma triterpenes are important secondary metabolites of G. lucidum. Ganoderma triterpenes are limestone-tetracyclic terpenes which have been reported to possess antioxidant, antitumor, anti-human immunodeficiency virus, anticancer, anti-inflammation, cytotoxic, hepatoprotective, and neuroprotective activities. This review deals with most important triterpenes isolated from Ganoderma and their therapeutic effects.
\end{abstract}

Key Words: Ganoderma; secondary metabolites; triterpenes; anticancer; antioxidant

(C) 2019 The Authors. Published by Innovare Academic Sciences Pvt Ltd. This is an open access article under the CC BY license (http://creativecommons. org/licenses/by/4. 0/) DOI: http://dx.doi.org/10.22159/ajpcr.2019.v12i4.32124

\section{INTRODUCTION}

Ganoderma is a wood-rotting mushroom with hard fruiting body and grows on decaying tree stumps or logs. Ganoderma is known by various popular names as "Reishi" in Japan, "Lingzhi" in China, and "Yeongji" in Korea. The taxonomical studies have reported about 300 species which belong to genus Ganoderma and the majority of which are distributed in tropical regions. Species of Ganoderma are corky, tough, and thick. Ganoderma does not have the fleshy texture and thus do not qualify to be considered as edible mushrooms [1,2]. Some of the important species of Ganoderma on which most of the research work on medical aspects have been carried out are as follows: Ganoderma lucidum, G. sinensis, G. theaecolum, G. zonatum, G. applanatum, G. pfeifferi, G. tsugae, G. resinaceum, G. amboinense, G. colossum, G. formosanum, G. australe, and G. atrium. G. lucidum is the most commonly characterized medicinal mushroom of the genus Ganoderma [3-8]. The more weight of Ganoderma mushroom is due to its high water content up to $90 \%$, which makes extracts of mushroom dehydrated powder and residual $10 \%$ of its mass consist of protein (10-40\%), carbohydrate (3-28\%), fiber (3-32\%), fat (28\%), and ash (8-10\%). Besides, various other compounds such as provitamin D2 [9], C19 fatty acids [10], and essential nutrients such as copper and zinc [11] have also been found to be present. With the minerals potassium, calcium, phosphorous, magnesium, selenium, iron, zinc, and copper represent most of the mineral content $[12,13]$. Rex, 2014 [14], reported that G. lucidum contains about $72 \mu \mathrm{g} \mathrm{Se} / \mathrm{g}$ of dry weight and thus can act as a good source of essential micronutrients like selenium. G. lucidum is found across the world and is considered as an effective supplement for the prevention and treatment of many diseases since ages. Triterpenes and polysaccharides from G. lucidum have been found to possess anti-inflammatory and antioxidant activity. The polysaccharide and the water extract from G. lucidum have shown to possess immune modulator and antitumor activities. In addition, G. lucidum have a wide variety of bioactive compounds such as terpenoids mostly triterpenoids, carbohydrates including polysaccharides and glycoproteins, steroids, phenolic compounds, nucleotides, and their derivatives. The proteins of Ganoderma mushroom contain different essential amino acids. Lysine and leucine represent the highest percentages. G. lucidum, also contains a large share of polyunsaturated fatty acids as compared to the total fatty acids, which are the highest contributors for the best human health $[6,12]$.
Ganoderma has been generally admitted as nutritional supplement across the world due to its long-term safety and tolerance. G. lucidum possess a vast array of medicinal properties. The extremely important G. lucidum in oriental traditional medicine has been used as remedy against various chronic diseases such as antitumor $[15,16]$, antioxidant [17], immunoregulation [18,19], hepatoprotection [20], hypoglycemic effect [21,22], antibacterial activity [23], reduction of blood cholesterol [24,25], inhibition of angiogenesis [26,27], antifibrotic activity [28], anti-human immunodeficiency virus (HIV) activity [29], and reduction of lower urinary tract symptoms [30]. The above bioactivities of Ganoderma have been found due to the important bioactive substances such as polysaccharides and triterpenoids. Despite the vast array of reported medicinal attributes of Ganoderma; however, the pathways and mechanisms of action of these bioactive substances from Ganoderma remain poorly defined. With further advancement in modern research technologies, clear and detailed insights into these pathways and mechanisms of action are becoming increasingly possible in which G. lucidum can influence the observed health benefits. Understanding these mechanisms could lead to more robust use of Ganoderma as an anticarcinogenic agent. With improvement in techniques, better separation and purification methods have proved very beneficial for the isolation and identification of bioactive substances from G. lucidum. However, modern researchers have primarily focused more on two active components, namely triterpenes and polysaccharides. In the foregoing account, emphasis has been given on the research work carried out by different scientists on major bioactive triterpenoids found in G. lucidum and other species of Ganoderma.

\section{TRITERPENES}

Triterpenes are biologically active compounds which contribute to the vast array of medicinal and health benefits of G. lucidum [12,31]. Triterpenes are a subtype of terpenes and are composed of six isoprene units. These isoprene units of terpenes usually form linear chains or ring-like structures. Ganoderic acids (GAs) represent a subtype of triterpenes with four cyclic and two linear isoprene units [32]. About 140 subtypes of GAs have been reported and identified from G. lucidum [33]. >130 triterpenoids (Lanostane type) have been isolated from fruiting bodies, spores, mycelia, and cultures of G. lucidum. They 
Table 1: Triterpenoids from Ganoderma and their bioactivity

\begin{tabular}{|c|c|c|c|}
\hline Mushroom & Bioactive compound & Bioactivity & References \\
\hline G. lucidum & GA T & $\begin{array}{l}\text { Shows anticancer activity against lung: 95D, liver: } \\
\text { KB-A-1: KB-3-1, cervix: SMMC7721, epidermis: HCT-116 } \\
\text { melanoma, HeLa colon: Ls174t, lung: A375, colon: LLC } \\
\text { cell lines. It inhibited the growth and proliferation of } \\
\text { these cancer cells }\end{array}$ & {$[41,42,120,121]$} \\
\hline G. lucidum & GA D & $\begin{array}{l}\text { It shows apoptotic activity against cervical: HeLa cell } \\
\text { line and inhibited cell proliferation }\end{array}$ & {$[33,43,100]$} \\
\hline G. lucidum & GA Me & $\begin{array}{l}\text { It shows cytotoxic activity against breast: MDA-MB-231, } \\
\text { lung: } 95-\mathrm{D} \text {, colon: HCT-116, HCT-8 cell lines. It arrests } \\
\text { cell cycle, targets p53, and inhibited cell proliferation, } \\
\text { migration, invasion, and induced apoptosis }\end{array}$ & {$[91,124-128]$} \\
\hline G. lucidum & GA Mc & $\begin{array}{l}\text { It shows cytotoxic activity against lung: 95D, cervical: } \\
\text { HeLa cell lines }\end{array}$ & {$[124,129]$} \\
\hline G. lucidum & Lucialdehydes A C & Shows cytotoxic activity & {$[45]$} \\
\hline G. lucidum & $\begin{array}{l}3 \alpha, 22 \beta \text {-diacetoxy- } 7 \alpha \text { hydroxyl } \\
-5 \alpha \text {-lanost-8, 24E-dien-26-oic acid }\end{array}$ & $\begin{array}{l}\text { It shows cytotoxic activity against lung: 95D, cervical: } \\
\text { HeLa cell lines }\end{array}$ & [130] \\
\hline G. lucidum & GA MK & $\begin{array}{l}\text { It shows cytotoxic activity against lung: 95D, cervical: } \\
\text { HeLa cell lines }\end{array}$ & {$[130,131]$} \\
\hline G. lucidum & GA Mf/S & $\begin{array}{l}\text { It shows cytotoxic activity against lung: 95D, cervical: } \\
\text { HeLa cell lines }\end{array}$ & {$[124,129]$} \\
\hline G. lucidum & GA R & $\begin{array}{l}\text { It shows cytotoxic activity against lung: 95D, cervical: } \\
\text { HeLa cell lines }\end{array}$ & {$[130]$} \\
\hline G. lucidum & Colossolactone $\mathrm{H}$ & Shows apoptotic activity & [132] \\
\hline G. lucidum & Ganodermanontetrol & Shows cytotoxic activity & [133] \\
\hline G. lucidum & Ganodermanontriol & $\begin{array}{l}\text { It inhibited cell proliferation in the breast: MDA-MB-231, } \\
\text { colon: HCT-116, HT- } 29 \text { cell lines }\end{array}$ & {$[134]$} \\
\hline G. lucidum & $\begin{array}{l}3 \beta, 24 \mathrm{~S}, 25 \mathrm{R}, 26 \text {-tetradroxy-7 } \alpha \text {-methoxy } \\
\text {-8-ene-lanost-ol }\end{array}$ & Shows cytotoxic activity & [133] \\
\hline G. lucidum & $12 \alpha$-methoxy-ganodermanondiol & Shows cytotoxic activity & [133] \\
\hline G. lucidum & $15 \beta$-hydroxy-lucidumol A & Shows cytotoxic activity & [133] \\
\hline G. lucidum & $15 \alpha$-hydroxy-ganodermanontriol & Shows cytotoxic activity & [133] \\
\hline G. lucidum & Lucidinic acid, $\mathrm{O}$ and lucidinic lactones & Inhibited HIV Type 1 reverse transcriptase & [87] \\
\hline G. pfeifferi & Ganoderone A & Inhibitory activity against herpes simplex virus & [137] \\
\hline G. lucidum & Lucialdeyde B & Shows cytotoxic activity & [45] \\
\hline G. lucidum & $\begin{array}{l}15 \alpha, 26 \text { dihydroxy-5 } \alpha \text {-lanostane- } \\
7,9,24(\text { E)-triene-3-one }\end{array}$ & $\begin{array}{l}\text { It shows cytotoxic activity against human HeLa cervical } \\
\text { cancer cell line }\end{array}$ & {$[95]$} \\
\hline G. lucidum & $\begin{array}{l}\text { 23S-hydroxy-3, 7, 11, } \\
\text { 15- tetraoxolanost-8, 24E-diene-26-oic } \\
\text { acid }\end{array}$ & $\begin{array}{l}\text { It shows cytotoxic activity against HeLa, p388, } \\
\text { SGC-7901, BEL-7402 human cancer cell lines }\end{array}$ & [48] \\
\hline G. lucidum & $\begin{array}{l}12 \beta \text {-Acetoxy-3 } \beta \text {-hydroxy- 7,11,15,23 } \\
\text {-tetraoxolanost- 8,20 E-diene-26-oic acid }\end{array}$ & $\begin{array}{l}\text { It shows cytotoxic activity against HeLa, p388, } \\
\text { SGC-7901, BEL-7402 human cancer cell lines }\end{array}$ & [48] \\
\hline G. lucidum & GAs $\gamma, \delta, \varepsilon, \zeta, \eta$ & Studied against Meth-A and LLC tumor cell lines & [36] \\
\hline G. sinensis & GA Jc & Showed selective inhibition against HL-60 cells & [9] \\
\hline G. lucidum & Ganoderiol E & Shows cytotoxic activity against MCF-7 cells & [138] \\
\hline G. lucidum & GA A & $\begin{array}{l}\text { Strong cytotoxic activity against breast: MDA-MB- } 231 \text {. } \\
\text { Inhibited growth and invasive behavior of breast cancer } \\
\text { cells }\end{array}$ & {$[100,110,123]$} \\
\hline G. lucidum & $\mathrm{GA}, \mathrm{H}$ & $\begin{array}{l}\text { Strong cytotoxic activity against breast: MDA-MB- } 231 \text {. } \\
\text { Inhibited growth and invasive behavior of breast cancer } \\
\text { cells }\end{array}$ & [123] \\
\hline G. lucidum & GA C1 & Strong cytotoxic activity & [45] \\
\hline G. pfeifferi & Lucialdehyde D & Strong cytotoxic activity & [137] \\
\hline G. lucidum & Lucialdehyde E & Strong cytotoxic activity & [139] \\
\hline G. tsugae & Tsugaric acid A & Significant activity against T-24 and HT- 3 cells & {$[140]$} \\
\hline G. tsugae & Tsugarioside A & Activity against T-24 cells & [51] \\
\hline G. tsugae & $\begin{array}{l}3 \beta \text {-Hydroxy-5 } \alpha \text {-lanosta-8,24-diene - } \\
21 \text {-oic acid }\end{array}$ & Activity against CaSKi cells & {$[51]$} \\
\hline G. amboinense & GA X & $\begin{array}{l}\text { Activity against liver: HuH-7, colon: HCT-116 cell lines } \\
\text { and inhibits topoisomerase and induces apoptosis of } \\
\text { cancer cells }\end{array}$ & [68] \\
\hline G. resinaceum & $\begin{array}{l}3 \alpha \text {-(3-Hydroxy-5- methoxy-3-methyl-1,5 } \\
\text { dioxopentyloxy)-24 methylene- } 5 \alpha \text { - } \\
\text { lanost-8-en-21-oic acid }\end{array}$ & Significant cytotoxic activity & {$[47]$} \\
\hline
\end{tabular}


Table 1: (Continued)

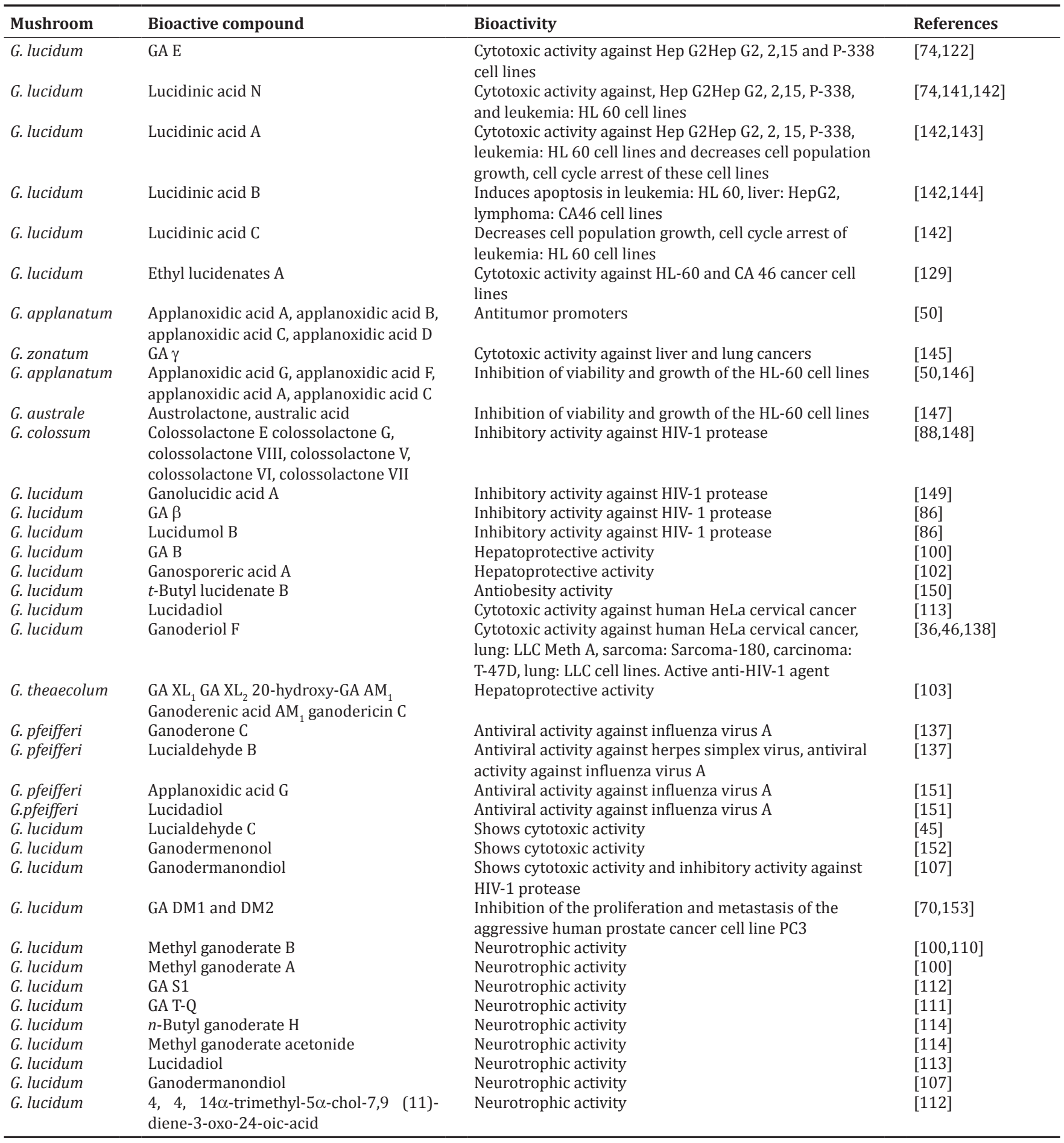

HeLa: Human epithelial cell line, HepG2: Hydroperoxide in human hepatic, HIV: Human immunodeficiency virus, G. lucidum: Ganoderma lucidum, GA: Ganoderic acids

have molecular weights ranging from 400 to $600 \mathrm{KDa}$. Triterpenes isolated from Ganoderma species show remarkable therapeutic and pharmacological properties on a number of human diseases including cancer pharmacological properties $[1,16,18,20,31,33]$. The triterpene extracts of G. lucidum are known to induce apoptosis of multiple human cancer cell lines [16]. However, the cytotoxic activity of triterpenes varied significantly across different subtypes of triterpenes [16]. Most triterpenoids extracted and identified from Ganoderma have shown robust biological activities (Table 1). The GAs isolated from Ganoderma have shown antiviral, anticancer, antioxidant, hepatoprotective, cytotoxic, antiplatelet aggregation, and inhibition of histamine release and hypocholesterolemic activities [7,34-40]. The most abundant triterpenic acid from $G$. lucidum is GA $\mathrm{T}$ which shows significant anticancer activity both in vivo and in vitro experiments [41,42]. GA has been found to inhibit tumor invasion by inhibiting matrix metalloproteinase (MMP)-9 expressions [42]. Another triterpenic acid GA D has been shown to directly bind to $14-3-33$ protein [43] and this binding may contribute to the facilitation of apoptosis observed in human epithelial cell line (HeLa) cell [43]. Ganoderiol F (GA-F) a tetracyclic triterpene found in Ganoderma lucidum $[36,44]$ has shown 
significant cytotoxic activity against Sarcoma-180, Lewis lung carcinoma (LLC), Meth-A and T-47D cancer cell lines [36,45]. GA-F has also been demonstrated in vivo in rats with LLC tumor cells [46]. The other forms of the isolated triterpenes from Ganoderma lucidum have been reported to show cytotoxic activity in the p338, HeLa, human hepatoma cell line (BEL-7402), and human gastric cancer cell line (SGC-7901) [47,48]. Recently, Hsu et al., 2018 [49], tested a new atheroprotective effect of G. lucidum, an arterial condition which is associated with chronic oxidative stress and inflammation, using a carotid artery ligation mouse model. In this study, the ligation of the artery generated disturbed blood flow, a critical atherogenic factor with no cure currently. These authors studied that G. lucidum protected arteries from disturbed flow-induced atherogenesis and the triterpenoid fraction is the critical constituents for these effects. Ganoderma triterpenoids alleviated oxidative stress and inflammation, thereby preventing neointimal hyperplasia in the ligated arteries through daily oral dosage after 2 weeks. Specific triterpenes or a mixture of triterpenes have been isolated and identified from G. lucidum and other species of Ganoderma with various health benefits, the results of which have been published. The various health benefits of Ganoderma triterpenes are as follows.

\section{Anticancer activities}

The triterpene extracts identified from G. lucidum and other Ganoderma species have shown anticancer property under in vivo conditions $[12,33,50-52]$. The carcinogenic effects shown by various types of extracts from G. lucidum include various cancer cell lines (breast, colon, lung, pancreas, prostate, and skin) [12,52]. The known mechanisms through which the extracts of $G$. lucidum exhibit anticancer activities include direct inhibition of cell proliferation through cancerspecific cell cycle arrest and apoptosis [41,53-55]. G. lucidum extracts, in addition, can lead to downregulation of cell cycle-associated proteins, resulting in cell cycle arrest $[54,56,57]$. Studies of the triterpene extracts from $G$. lucidum have shown that these extracts can arrest the cell cycle at the G1 phase $[54,55]$. The mechanism for this inhibition of cell cycle at G1 phase is by the downregulation of cyclin D1 through the modulation of the $\beta$-catenin pathways [58]. Cyclin D1 is the key regulator of cyclin-dependent kinase which is very important for the transition of G1/S phase of the cell cycle [59]. About $30 \%$ of colon cancer has an overexpression of cyclin D1, due to the abnormal $\beta$-catenin signaling pathway [60]. The triterpene from G. lucidum, ganodermanontriol has been found to inhibit the proliferation of human colorectal carcinoma cell lines (HCT116 and HT-29) by inhibiting the expression of $\beta$-catenin, thus controlled levels of cyclin D1 is expressed [54]. The triterpene extracts from Ganoderma can also cause inhibition of G2/M transition, apart from inhibiting G1 phase of cell cycle [38]. It has been studied that the triterpene extract of Ganoderma can suppress the activity of protein kinase C (PKC), leading to a prolonged G2 phase, by treatment with the triterpene-enriched ethanol soluble fractions (WEES-G6). PKC is selectively activated during G2 phase of the cell cycle and belongs to the class of serine-threonine protein kinases [61]. During the G2 phase of the cell cycle, PKC has been found to be involved in the regulation of nuclear disassembly [62]. Various studies have reported that the use of PKC inhibitors can arrest the G2 phase of the cell cycle $[63,64]$. In addition, the level of cycling $\mathrm{B}$, a kinase, which is responsible for the transition from G2 to M phase, is reduced by WEES-G6 [38]. Due to the activity of WEES-G6, the c-Jun N-terminal kinase (JNK) and p38 kinase, both of which are mitogen-activated protein kinase which responded to cellular stress are activated [38]. JNK is considered very critical regulator of transcription which can activate tumor suppressors such as p53 [65-67]. Johnson and Lapadat [67] observed cell cycle arrest in triterpene-treated human hepatoma (HuH-7) carcinoma, but no effect has been seen in a normal human liver cell line, which further supports the use of triterpenes as therapeutic anticancer agent. Jiang et al., 2004 [52], reported that G. lucidum suppress the growth of breast cancer cells through the inhibition of Akt/NF-Kappa B signaling. How the triterpene-induced G2 phase cell cycle arrest occurs. Li et al., 2005 [68], identified the inhibition of DNA synthesis through the inhibition of topoisomerase as the possible mechanism of GA X-induced cell cycle arrest. Tang et al., 2006 [41], observed that GA from G. lucidum mycelia induces mitochondria-mediated apoptosis in lung cancer cells. Similarly, Chen et al., 2010 [42], revealed that GA T from G. lucidum inhibits the tumor growth through inhibition of MMP expression.

A recent study by researchers reported that gold nanoparticles (Au-NPs) synthesized from G. lucidum and then conjugated with drug doxorubicin show robust and significant anticancer drug accumulation and cytotoxic activity against MCF-7-doxbreast cancer cell line. AuNPs efficiently inhibited the growth of MCF-7-doxbreast cancer cell line at higher concentration $(400 \mu \mathrm{M} / \mathrm{ml})$ by $97 \%$. mRNA expression of ABCB1 gene and CDNA synthesized from human breast cancer cell line (MCF-7) showed reduced expression. It is important to conclude that the pharmacological activity of G. lucidum exhibits the anticancer activity of newly synthesized Au-NPs conjugated with drug doxorubicin. However, further research is required under in vivo conditions to report toxicity if any, due to newly synthesized Au-NPs. Au-NPs synthesized from G. lucidum conjugated with drug doxorubicin could prove as possible and strong source of drug delivery for anticancer inducing drug preparation which can benefit treatment of breast cancers [69].

\section{Cytotoxic activities}

The triterpene extracts identified from G. lucidum have been to show cytotoxic effects under in vitro conditions (on cancer cell lines) [12]. Various cytotoxic compounds from $G$. lucidum have been found to trigger apoptosis, leading to programmed cell death $[52,53]$. The triterpenes from $G$. lucidum also observe to cause apoptosis of various cancer cell lines, and this has been found to be due to the increase of proapoptotic proteins and decrease of antiapoptotic proteins $[41,53]$. The structure-activity relationship of GA-DM was investigated and it was shown to inhibit the proliferation of the aggressive human prostate cancer cell line PC3 [70].

The mechanisms by which triterpenes from G. lucidum induce apoptosis in human cancer cell lines include mitochondria-dependent pathway followed by activation of caspase cascade [70,71]. The mitochondrialdependent apoptotic pathway also known as intrinsic apoptotic pathway involves the decrease in mitochondrial potential followed by the release of cytochrome $c$ from the mitochondria $[72,73]$. The cytochrome $\mathrm{c}$ which is released from the mitochondria into the cytosol is known to trigger the caspase cascade which leads to apoptosis. This caspase cascade involves caspase 9 and caspase 3 which have been studied to have higher expressions in different human cancer cell lines when treated with the triterpenes extract from G. lucidum [41,71,74]. The release of cytochrome $\mathrm{c}$ depends on the ratio of $\mathrm{Bax} / \mathrm{Bcl}-2$ balance [75]. It has also been observed that when the ratio of Bax/Bcl2 is increased, apoptosis is triggered. The Bcl-2 family proteins can be either proapoptotic or antiapoptotic. Bcl-2 associated X protein (Bax) and Bcl-2 associated death promoter (Bad) are proapoptotic while as Bcl-2 is antiapoptotic. Various studies have revealed that during the treatment of different human cancer cell lines with the triterpenes of $G$. lucidum, the ratio of Bax/Bcl-2 is increased which, therefore, increases Bax expression while downregulating Bcl-2 expression [71]. Liu et al., 2012 [70], observed cytotoxic and proapoptotic effect of GA derivatives on human cervical cancer cells under in vitro conditions.

\section{Antioxidant activity}

The major contributor to increased cancer risk is known to be the oxidative stress. Reactive oxygen species (ROS) and free radicals are produced as by-products of metabolic processes involving redox enzymes and electron transfer during bioenergetics, as well as due to exposure to some exogenous chemicals [76]. Free radicals and ROS can damage cells and tissues by the process of oxidation and long-term accumulation of such damage due to free radicals and ROS causes aging and various age-associated diseases [77]. ROS and free radicals have the potential to cause damage to proteins and DNA within cells, leading to oxidative stress, which can be countered by antioxidative enzymes and repair mechanisms. However, it has been observed that excessive oxidative stress can override the innate protective system, leading to a variety of physiological disorders including cancer [78]. These cancer 
cells further contribute to cancer progression by generating increased levels of free radicals relative to normal cells [78]. Various studies have suggested that this cancer-causing damage might be reduced or prevented with the help of antioxidants from the extracts of Ganoderma species $[78,79]$.

Various other studies have also shown that the triterpene extracts of G. lucidum have antioxidant activity and have the potential to reduce oxidative damage by directly scavenging free radicals generated in the cell due to the increase in the activity of superoxide dismutase and catalase which are enzymes involved in removing harmful free radicals and ROS [80,81]. Smina et al., 2011 [82,83], revealed in mice that triterpenes from $G$. lucidum showed antioxidant activity which may be due to increased activity of antioxidant enzymes and they further observed that total terpenes from G. lucidum prevent radiation-induced DNA damage and apoptosis in splenic lymphocytes of mice under in vitro conditions. In a recent study by Smina et al., 2016 [84], total triterpenes from $G$. lucidum were highly effective in reducing the levels of lipid peroxidation and protein oxidation to near normal values in both liver and brain tissues in Swiss albino mice under in vivo conditions. Total triterpenes, when administered under vivo conditions, were also found to be successful in restoring the antioxidant enzyme activities and glutathione level in liver and brain of irradiated mice. Administration of total triterpenes, before radiation exposure, significantly decreased the DNA strand breaks.

\section{Anti-HIV activity}

HIV, which induces a lethal and incurable condition known as acquired immunodeficiency syndrome (AIDS), is a highly infectious virus affecting an estimated 35 million people all over the world [85]. The treatment strategies for HIV, which are currently in use, involve delaying the progression of disease into AIDS [85]. Various compounds that exhibit inhibitory effects against AIDS have been identified from G. lucidum, and related species of Ganoderma such as triterpenes have shown anti-HIV-1 protease activity [22,86]. Mizushina et al., 1999 [87], observed the inhibition of HIV Type 1 transcriptase due to lucidinic acid and lucidinic lactones isolated from G. lucidum. el-Mekkawy et al., 1998 [29], have assayed 13 compounds for anti-HIV activity isolated from G. lucidum. El Dine et al., 2008 [88], observed anti-HIV-1 protease activity of triterpenoids from $G$. colosseum. The inhibitory activity of triterpenoids isolated from Ganoderma species against HIV has also been reported by Cassels and Asencio, 2011 [89]. Various compounds out of these have shown anti-HIV-1 activity, which includes GA A which showed robust activity against HIV proteases. However, muchextended research is to be carried out to ascertain a mechanistic basis for G. lucidum extracts and other species of Ganoderma as anti-HIV agents. In addition, determination of the structure-activity relationship between triterpenes from G. lucidum and HIV proteases must be performed as well.

\section{Antimetastatic potential}

Cancer metastasis is very complex phenomenon in which cancer cells split from the primary tumor cells and invade other tissues, thereby leading to the formation of secondary tumors. Cancer metastasis dramatically reduces the rate of survival and cure, when left untreated [90]. Several key proteins which are involved in metastasis of cancer may be regulated by triterpenes of G. lucidum and other species of Ganoderma [64,91]. MMP is a family of proteins which cause degradation of extracellular matrix and thereby promote cancer metastasis $[32,92,93]$. The triterpenoid GA-Me extracted from G. lucidum suppressed the invasion of 95-D, LLC, and HCT-116 metastatic cancer cell lines through inhibition of MMP-9 expression [75,94]. Chen et al. [95] revealed that GA T extracted from G. lucidum inhibits the tumor invasion through inhibition of MMP expression. Interleukin (IL-8) and various angiogenic factors such as vascular endothelial growth factor (VEGF) caused induction of angiogenesis and resulted in the promotion of metastasis [96]. It is further suggested that the expression of IL-8 is upregulated during oxidative stress, and therefore, overexpression of IL-8 is involved in the metastasis of breast cancer cell lines $[97,98]$. Studies have reported that oxidative-induced IL-8 expression was reduced in breast cancer cell lines after treatment with triterpenoid extracts of G. lucidum [99].

\section{Hepatoprotective activity}

It has been studied that GA B isolated from Ganoderma species showed significant hepatoprotection property [100]. However, it was observed that when the doses of GA B were increased 10 times than the normal, it did not further reduce glutamic oxaloacetic transaminase and glutamic pyruvic transaminase levels in the serum of the mice [101]. Chen and Yu, 1993 [102], have reported that ganosporic acid A has shown significant activity of lowering the levels of GPT in mice with liver injury by carbon tetrachloride $\left(\mathrm{CCL}_{4}\right)$ and exhibits hepatoprotective effect. Lin et al., 2003 [38], and Liu et al., 2014 [103], observed that triterpenoids such as GA XL, XL2, and ganoderic in from the extracts of $G$. lucidum and $G$. theaecolum have good hepatoprotective properties suppress the growth of hepatoma cells. Wu et al., 2016 [104], observed the hepatoprotective effects and mechanism of the action of triterpenoids from G. lucidum on $\alpha$-amanitin-induced liver injury in mice. Wu et al., 2016 [105], studied the hepatoprotective effect of Ganoderma triterpenoids against oxidative damage induced by tert-butyl hydroperoxide in human hepatic cells. GAs, namely, GAs R and $S$, from the cultured mycelium of $G$. lucidum have shown strong hepatoprotective activity in galactosamine-induced cytotoxicity in cultured rat hepatocytes. The triterpenoid extracts from Ganoderma can prevent liver damage induced by $\mathrm{CCL}_{4}$ and galactosamine in rats [106]. The triterpenoids from G. lucidum have shown significant protection against immunological liver damage in mice in vitro and in vivo.

\section{Neurotrophic activity}

Several studies have confirmed the neuroprotective activity of triterpenoids from Ganoderma species [107-109].Zhou et al., 2012 [109], reported neuroprotective effect of pre-administration of G. lucidum spores on rat hippocampus. Various studies have reported that the compounds, 4,4,14 $\alpha$-Trimethyl-5 $\alpha$-chol-7,9 (11)-diene-3-oxo-24-oicacid and methyl ganoderate $B$, have showed nerve growth factor-like neuronal survival-promoting effects $[100,110]$, whereas the compounds 4,4,14 $\alpha$-Trimethyl-5 $\alpha$-chol-7,9 (11)-diene-3-oxo-24-oic-acid, methyl ganoderate $\mathrm{B}$, methyl ganoderate $\mathrm{A}, \mathrm{GA} \mathrm{S} 1$, and GA T-Q showed brain-derived neurotrophic factor-like neuronal survival-promoting activities [100,110-112]. Compounds such as $n$-butyl ganoderate $\mathrm{H}$ and methyl ganoderate A acetonide have shown specific antiacetylcholine terse activity and have been examined as possible drug candidates for the treatment of Alzheimer's and other related neurodegenerative diseases. The compounds lucidadiol, ganodermanondiol, and other Ganoderma triterpenes have shown moderate acetylcholinesterase inhibitory activity [113]. These observations indicate that these lanostane triterpenes are potential inhibitors of acetylcholine esterase and may be considered as preferential drug candidates [114].

\section{Anti-inflammatory potential}

About $20 \%$ of the cancers are considered to be the result of inflammation $[115,116]$. The carcinogenesis is promoted due to the chronic overexpression of inflammatory cytokines such as IL-6, VEGF, and tumor necrosis factor- $\alpha[117,118]$. The administration of a triterpene extract of $G$. lucidum is known to suppress the inflammatory cytokine secretion in macrophage cells, therefore, reducing the level of inflammation [119].

\section{CONCLUSION}

The beneficial health attributes of Ganoderma species are due to the presence of various bioactive compounds. Ganoderma genus, in general, and G. lucidum, in particular, can be considered as a natural pharmacy store besides being natural therapeutic machinery. There are two main groups of bioactive substances triterpenes and polysaccharides that have been studied in detail. Triterpenoids have been reported as having cytotoxic, hepatoprotective, anti-inflammatory, anti-HIV, neurotrophic, along with antitumor, anticancer, and antioxidant activities. In addition, because the various bioactive compounds isolated from G. lucidum 
did not show any toxic side effects, the demand for this mushroom as health fortifying food, a natural remedy, and dietary food is increasing day by day and attracting the interests of the scientific community and industrial community as well. However, due to the lack of results, intense investigation needs to be performed in the field (e.g., human clinical trials). Till now, the available data suggest that G. lucidum has a high potential to be accepted as a good health food supplement for patients experiencing cancer therapy. This available knowledge and further investigation would facilitate the development of new nutraceuticals and pharmacological formulations.

\section{CONFLICTS OF INTEREST}

It is hereby stated that the above article is consented for publication by all authors in this journal and, therefore, declares no conflicts of interest.

\section{REFERENCES}

1. Jong SC, Birmingham JM. Medicinal benefits of the mushroom Ganoderma. Adv Appl Microbiol 1992;37:101-34.

2. Jonathan SG, Kigigha LT, Ohimain E. Evaluation of the inhibitory potentials of eight higher Nigerian fungi against pathogenic microorganisms. Afr J Biomed Res 2008;11:197-202.

3. Leung SW, Yeung KY, Ricky YL, Man YK. Lingzhi (Ganoderma) Research the Past, Present and Future Perspectives in Ganoderma: Genetics, Chemistry, Pharmacology and Therapeutics Proceedings of International Symposium on Ganoderma Research. Beijing: Beijing Medical University Press; 2002. p. 1-9.

4. Paterson RR. Ganoderma a therapeutic fungal biofactory. Phytochemistry 2006;67:1985-2001.

5. Ziegenbein FC, Hanssen HP, König WA. Secondary metabolites from Ganoderma lucidum and Spongiporus leucomallellus. Phytochemistry 2006;67:202-11.

6. Sanodiya BS, Thakur GS, Baghel RK, Prasad GB, Bisen PS. Ganoderma lucidum: A potent pharmacological macrofungus. Curr Pharm Biotechnol 2009;10:717-42.

7. Ríos JL, Andújar I, Recio MC, Giner RM. Lanostanoids from fungi: A group of potential anticancer compounds. J Nat Prod 2012;75:2016-44.

8. Rios JL, Andujar I. Lanostanoids from fungi as potential medicinal agents. Fungal Metab 2017:931-64.

9. Liu JQ, Wang CF, Li Y, Luo HR, Qiu MH. Isolation and bioactivity evaluation of terpenoids from the medicinal fungus Ganoderma sinense. Planta Med 2012;78:368-76.

10. Gao P, Hirano T, Chen Z, Yasuhara T, Nakata Y, Sugimoto A, et al. Isolation and identification of C-19 fatty acids with anti-tumor activity from the spores of Ganoderma lucidum (reishi mushroom). Fitoterapia 2012;83:490-9.

11. Matute RG, Serra A, Figlas D, Curvetto N. Copper and zinc bioaccumulation and bioavailability of Ganoderma lucidum. J Med Food 2011;14:1273-9.

12. Wachtel-Galor S, Yuen J, Buswell JA, Benzie IFF. Ganoderma lucidum (Lingzhi or Reishi): A medicinal mushroom. In: Herbal Medicine: Bimolecular and Clinical Aspects: Boca Raton, USA: CRC Press Taylor and Francis; 2011.

13. Cör D, Knez Ž, Knez Hrnčič M. Antitumour, antimicrobial, antioxidant and antiacetylcholinesterase effect of Ganoderma lucidum terpenoids and polysaccharides: A Review. Molecules 2018;23:649.

14. Rex DA. Selenium enriched mushrooms as a food supplement for prevention of neurodegenerative diseases. Int J Pharm Pharm Sci 2014;6:1-2.

15. Wang SY, Hsu ML, Hsu HC, Tzeng CH, Lee SS, Shiao MS, et al. The antitumor effect of Ganoderma lucidum is mediated by cytokines released from activated macrophages and T lymphocytes. Int J Cancer 1997; 70:699-705.

16. Yuen JW, Gohel MD. Anticancer effects of Ganoderma lucidum: A review of scientific evidence. Nutr Cancer 2005;53:11-7.

17. Yen GC, Wu JY. Antioxidant and radical scavenging properties of extracts from Ganoderma tsugae. Food Chem 1999;65:375-9.

18. Wasser SP. Medicinal mushrooms as a source of antitumor and immunomodulating polysaccharides. Appl Microbiol Biotechnol 2002; 60:258-74.

19. Lin ZB, Zhang HN. Anti-tumor and immunoregulatory activities of Ganoderma lucidum and its possible mechanisms. Acta Pharmacol Sin 2004;25:1387-95.
20. Kim HW, Kim BK. Biomedicinal triterpenoids of Ganoderma lucidum (Curt:Fr.)P.Karst.(Aphyllophoromycetidae).IntJMedMushrooms 1999; 1:121-38.

21. Hikino H, Konno C, Mirin Y, Hayashi T. Isolation and hypoglycemic activity of ganoderans A and B, glycans of Ganoderma lucidum fruit bodies. Planta Med 1985;51:339-40.

22. Sato N, Zhang Q, Ma CM, Hattori M. Anti-human immunodeficiency virus-1 protease activity of new lanostane-type triterpenoids from Ganoderma sinense. Chem Pharm Bull (Tokyo) 2009;57:1076-80.

23. Gao Y, Tang W, Gao H, Chan E, Lan J, Li X, et al. Antimicrobial activity of the medicinal mushroom Ganoderma. Food Rev Int 2005; 21:211-29.

24. Mizuno T, Wang G, Zhang J, Kawagishi H, Nishitoba T, Reishi LJ. Ganoderma lucidum and Ganoderma tsugae: Bioactive substances and medicinal effects. Food Rev Int 1995;11:151-66.

25. Berger A, Rein D, Kratky E, Monnard I, Hajjaj H, Meirim I, et al. Cholesterol-lowering properties of Ganoderma lucidum in vitro, ex vivo, and in hamsters and minipigs. Lipids Health Dis 2004:3:2.

26. Stanley G, Harvey K, Slivova V, Jiang J, Sliva D. Ganoderma lucidum suppresses angiogenesis through the inhibition of secretion of VEGF and TGF-betal from prostate cancer cells. Biochem Biophys Res Commun 2005;330:46-52.

27. Hsu SC, Ou CC, Chuang TC, Li JW, Lee YJ, Wang V, et al. Ganoderma tsugae extract inhibits expression of epidermal growth factor receptor and angiogenesis in human epidermoid carcinoma cells: In vitro and in vivo. Cancer Lett 2009;281:108-16.

28. Park EJ, Ko G, Kim J, Sohn DH. Antifibrotic effects of a polysaccharide extracted from Ganoderma lucidum, glycyrrhizin, and pentoxifylline in rats with cirrhosis induced by biliary obstruction. Biol Pharm Bull 1997; 20:417-20.

29. el-Mekkawy S, Meselhy MR, Nakamura N, Tezuka Y, Hattori M, Kakiuchi N, et al. Anti-HIV-1 and anti-HIV-1-protease substances from Ganoderma lucidum. Phytochemistry 1998;49:1651-7.

30. Noguchi M, Kakuma T, Tomiyasu K, Kurita Y, Kukihara H, Konishi F, et al. Effect of an extract of Ganoderma lucidum in men with lower urinary tract symptoms: A double-blind, placebo-controlled randomized and dose-ranging study. Asian J Androl 2008;10:651-8.

31. Shi L, Ren A, Mu D, Zhao M. Current progress in the study on biosynthesis and regulation of ganoderic acids. Appl Microbiol Biotechnol 2010;88:1243-51.

32. Liu J, Kurashiki K, Fukuta A, Kaneko S, Suimi Y, Shimizu K, et al. Quantitative determination of the representative triterpenoids in the extracts of Ganoderma lucidum with different growth stages using high-performance liquid chromatography for evaluation of their 5 $\alpha$-reductase inhibitory properties. Food chem 2012;133:1034-38.

33. Yue QX, Song XY, Ma C, Feng LX, Guan SH, Wu WY, et al. Effects of triterpenes from Ganoderma lucidum on protein expression profile of heLa cells. Phytomedicine 2010;17:606-13.

34. Sonoda Y, Sekigawa Y, Sato Y. In vitro effects of oxygenated lanosterol derivatives on cholesterol biosynthesis from 24,25-dihydrolanosterol. Chem Pharm Bull (Tokyo) 1988;36:966-73.

35. Komoda Y, Shimizu M, Sonoda Y, Sato Y. Ganoderic acid and its derivatives as cholesterol synthesis inhibitors. Chem Pharm Bull (Tokyo) 1989;37:531-3.

36. Min BS, Gao JJ, Nakamura N, Hattori M. Triterpenes from the spores of Ganoderma lucidum and their cytotoxicity against meth-A and LLC tumor cells. Chem Pharm Bull (Tokyo) 2000;48:1026-33.

37. González AG, León F, Rivera A, Padrón JI, González-Plata J, Zuluaga JC, et al. New lanostanoids from the fungus Ganoderma concinna. J Nat Prod 2002;65:417-21.

38. Lin SB, Li CH, Lee SS, Kan LS. Triterpene-enriched extracts from Ganoderma lucidum inhibit growth of hepatoma cells via suppressing protein kinase $\mathrm{C}$, activating mitogen-activated protein kinases and $\mathrm{G} 2$ phase cell cycle arrest. Life Sci 2003;72:2381-90.

39. You BJ, Lee MH, Tien N, Lee MS, Hsieh HC, Tseng LH, et al. A novel approach to enhancing ganoderic acid production by Ganoderma lucidum using apoptosis induction. PLoS One 2013;8:e53616.

40. Chudzik M, Korzonek-Szlacheta I, Król W. Triterpenes as potentially cytotoxic compounds. Molecules 2015;20:1610-25.

41. Tang W, Liu JW, Zhao WM, Wei DZ, Zhong JJ. Ganoderic acid T from Ganoderma lucidum mycelia induces mitochondria mediated apoptosis in lung cancer cells. Life Sci 2006;80:205-11.

42. Chen NH, Liu JW, Zhong JJ. Ganoderic acid T inhibits tumor invasion in vitro and in vivo through inhibition of MMP expression. Pharmacol Rep 2010;62:150-63.

43. Yue QX, Cao ZW, Guan SH, Liu XH, Tao L, Wu WY, et al. Proteomics characterization of the cytotoxicity mechanism of ganoderic acid 
D and computer-automated estimation of the possible drug target network. Mol Cell Proteomics 2008;7:949-61.

44. Chang UM, Li CH, Lin LI, Huang CP, Kan LS, Lin SB, et al. Ganoderiol F, a Ganoderma triterpene, induces senescence in hepatoma hepG2 cells. Life Sci 2006;79:1129-39.

45. Gao JJ, Min BS, Ahn EM, Nakamura N, Lee HK, Hattori M, et al. New triterpene aldehydes, lucialdehydes A-C, from Ganoderma lucidum and their cytotoxicity against murine and human tumor cells. Chem Pharm Bull (Tokyo) 2002;50:837-40.

46. Gao JJ, Hirakawa A, Min BS, Nakamura N, Hattori M. In vivo antitumor effects of bitter principles from the antlered form of fruiting bodies of Ganoderma lucidum. J Nat Med 2006;60:42-8.

47. Niu XM, Li SH, Xiao WL, Sun HD, Che CT. Two new lanostanoids from Ganoderma resinaceum. J Asian Nat Prod Res 2007;9:659-64.

48. Guan SH, Xia JM, Yang M, Wang XM, Liu X, Guo DA, et al. Cytotoxic lanostanoid triterpenes from Ganoderma lucidum. J Asian Nat Prod Res 2008;10:705-10.

49. Hsu PL, Lin YC, Ni H, Mo FE. Ganoderma triterpenoids exert antiatherogenic effects in mice by alleviating disturbed flowinduced oxidative stress and inflammation. Oxid Med Cell Longev 2018;2018:3491703.

50. Tokuyama T, Hayashi Y, Nishizawa M, Tokuda H, Chairul SM, Hayashi Y. Applanoxidic acids A, B, C and D, biologically active tetra cyclic triterpenes from Ganoderma applanatum. Phytochemistry 1991;30:4105-9.

51. Su HJ, Fanny F, Chung MI. New lanostanoids of Ganoderma tsugae. J Nat Prod 2000;63:514-6.

52. Jiang J, Slivova V, Harvey K, Valachovicova T, Sliva D. Ganoderma lucidum suppresses growth of breast cancer cells through the inhibition of Akt/NF-kB signaling. Nutr Cancer 2004;49:209-16.

53. Fukuzawa M, Yamaguchi R, Hide I, Chen Z, Hirai Y, Sugimoto A, et al. Possible involvement of long chain fatty acids in the spores of Ganoderma lucidum (Reishi houshi) to its anti-tumor activity. Biol Pharm Bull 2008:31:1933-7.

54. Jedinak A, Thyagarajan-Sahu A, Jiang J, Sliva D. Ganodermanontriol, a lanostanoid triterpene from Ganoderma lucidum, suppresses growth of colon cancer cells through B-catenin signaling. Int J Oncol 2011; 38:761-7.

55. Wu G, Qian Z, Guo J, Hu D, Bao J, Xie J, et al. Ganoderma lucidum extract induces G1 cell cycle arrest, and apoptosis in human breast cancer cells. Am J Chin Med 2012;40:631-42.

56. Wu GS, Guo JJ, Bao JL, Li XW, Chen XP, Lu JJ, et al. Anti-cancer properties of triterpenoids isolated from Ganoderma lucidum a review. Expert Opin Investig Drugs 2013;22:981-92.

57. Sliva D, Loganathan J, Jiang J, Jedinak A, Lamb JG, Terry C, et al. Mushroom Ganoderma lucidum prevents colitis-associated carcinogenesis in mice. PLoS One 2012;7:e47873.

58. Shtutman M, Zhurinsky J, Simcha I, Albanese C, D'Amico M, Pestell R, et al. The cyclin D1 gene is a target of the $\beta$-catenin/LEF-1 pathway. Proc Natl Acad Sci USA 1999; 96:5522-7.

59. Yan YX, Nakagawa H, Lee MH, Rustgi AK. Transforming growth factor-alpha enhances cyclin D1 transcription through the binding of early growth response protein to a cis-regulatory element in the cyclin D1 promoter. J Biol Chem 1997;272:33181-90.

60. Bartkova J, Lukas J, Strauss M, Bartek J. The PRAD-1/cyclin D1 oncogene product accumulates aberrantly in a subset of colorectal carcinomas. Int J Cancer 1994;58:568-73.

61. Thompson LJ, Fields AP. $\beta I I$ protein kinase $\mathrm{C}$ is required for the $\mathrm{G} 2 / \mathrm{M}$ phase transition of cell cycle. J Biol Chem 1996;271:15045-53.

62. Fishman DD, Segal S, Livneh E. The role of protein kinase C in G1 and G2/M phases of the cell cycle (review). Int J Oncol 1998;12:181-6.

63. Hofmann J, O'Connor PM, Jackman J, Schubert C, Ueberall F, Kohn KW, et al. The protein kinase C inhibitor ilmofosine (BM 41 440) arrests cells in G2 phase and suppresses CDC2 kinase activation through a mechanism different from that of DNA damaging agents. Biochem Biophys Res Commun 1994;199:937-43.

64. Arita Y, Buffolino P, Coppock DL. Regulation of the cell cycle at the G2/M boundary in metastatic melanoma cells by 12-O-tetradecanoyl phorbol-13-acetate (TPA) by blocking p34cdc2 kinase activity. Exp Cell Res 1998;242:381-90.

65. Liu Y, Guyton KZ, Gorospe M, Xu Q, Lee JC, Holbrook NJ. Differential activation of ERK, JNK/SAPK and P3/CSBP/RK map kinase family members during the cellular response to arsenite. Free Radic Biol Med 1996;21:771-81.

66. Price MA, Cruzalegui FH, Treisman R. The p38 and ERK MAP kinase pathways cooperate to activate Ternary Complex Factors and c-fos transcription in response to UV light. EMBO J 1996;15:6552-63.
67. Johnson GL, Lapadat R. Mitogen-activated protein kinase pathways mediated by ERK, JNK, and p38 protein kinases. Science 2002;298:1911-2.

68. Li CH, Chen PY, Chang UM, Kan LS, Fang WH, Tsai KS, et al. Ganoderic acid X, a lanostanoid triterpene, inhibits topoisomerases and induces apoptosis of cancer cells. Life Sci 2005;77:252-65.

69. Kumar DS, Senthilkumar P, Surendran L, Sudhagar B. Ganoderma lucidum oriental mushroom mediated synthesis of gold nanoparticles conjugated with doxorubicin and evaluation of its anticancer potential on human breast cancer MCF-7/DOX cells. Int J Pharm Pharm Sci 2017;9:267-74

70. Liu RM, Li YB, Zhong JJ. Cytotoxic and pro-apoptotic effects of novel ganoderic acid derivatives on human cervical cancer cells in vitro. Eur J Pharmacol 2012;681:23-33.

71. Liu RM, Zhong JJ. Ganoderic acid $\mathrm{mf}$ and $\mathrm{S}$ induce mitochondria mediated apoptosis in human cervical carcinoma heLa cells. Phytomedicine 2011;18:349-55.

72. Green D, Kroemer G. The central executioners of apoptosis: Caspases or mitochondria? Trends Cell Biol 1998;8:267-71.

73. Green DR, Reed JC. Mitochondria and apoptosis. Science 1998;281:1309-12.

74. Wu TS, Shi LS, Kuo SC. Cytotoxicity of Ganoderma lucidum triterpenes. J Nat Prod 2001;64:1121-2.

75. Zong WX, Li C, Hatzivassiliou G, Lindsten T, Yu QC, Yuan J, et al. Bax and bak can localize to the endoplasmic reticulum to initiate apoptosis. J Cell Biol 2003;162:59-69.

76. Yue GG, Fung KP, Tse GM, Leung PC, Lau CB. Comparative studies of various Ganoderma species and their different parts with regard to their antitumor and immunomodulating activities in vitro. J Altern Complement Med 2006;12:777-89.

77. Lobo V, Patil A, Phatak A, Chandra N. Free radicals, antioxidants and functional foods: Impact on human health. Pharmacogn Rev 2010;4:118-26

78. Dreher D, Junod AF. Role of oxygen free radicals in cancer development. Eur J Cancer 1996;32A:30-8.

79. Peng XR, Liu JQ, Han ZH, Yuan XX, Luo HR, Qiu MH, et al. Protective effects of triterpenoids from Ganoderma resinaceum on $\mathrm{H}_{2} \mathrm{O}_{2}$-induced toxicity in hepG2 cells. Food Chem 2013;141:920-6.

80. Ajith TA, Sudheesh NP, Roshny D, Abishek G, Janardhanan KK. Effect of Ganoderma lucidum on the activities of mitochondrial dehydrogenases and complex I and II of electron transport chain in the brain of aged rats. Exp Gerontol 2009;44:219-23.

81. Cherian E, Sudheesh NP, Janardhanan KK, Patani G. Free-radical scavenging and mitochondrial antioxidant activities of reishi Ganoderma lucidum (Curt: Fr) P. Karst and arogyapacha Trichopus zeylanicus gaertn extracts. J Basic Clin Physiol Pharmacol 2009;20:289-307.

82. Smina TP, De S, Devasagayam TP, Adhikari S, Janardhanan KK. Ganoderma lucidum total triterpenes prevent radiation-induced DNA damage and apoptosis in splenic lymphocytes in vitro. Mutat Res 2011;726:188-94

83. Smina TP, Mathew J, Janardhanan KK, Devasagayam TP. Antioxidant activity and toxicity profile of total triterpenes isolated from Ganoderma lucidum (Fr.) P. Karst occurring in South India. Environ Toxicol Pharmacol 2011;32:438-46.

84. Smina TP, Joseph J, Janardhanan KK. Ganoderma lucidum total triterpenes prevent $\gamma$-radiation induced oxidative stress in Swiss albino mice in vivo. Redox Rep 2016;21:254-61.

85. Paydary K, Khaghani P, Emamzadeh-Fard S, Alinaghi SA, Baesi K. The emergence of drug resistant HIV variants and novel anti-retroviral therapy. Asian Pac J Trop Biomed 2013;3:515-22.

86. Min BS, Nakamura N, Miyashiro H, Bae KW, Hattori M. Triterpenes from the spores of Ganoderma lucidum and their inhibitory activity against HIV-1 protease. Chem Pharm Bull (Tokyo) 1998;46:1607-12.

87. Mizushina Y, Takahashi N, Hanashima L, Koshino H, Esumi Y, Uzawa $\mathrm{J}$, et al. Lucidenic acid $\mathrm{O}$ and lactone, new terpene inhibitors of eukaryotic DNA polymerases from a basidiomycete, Ganoderma lucidum. Bioorg Med Chem 1999; 7:2047-52.

88. El Dine RS, El Halawany AM, Ma CM, Hattori M. Anti-HIV-1 protease activity of lanostane triterpenes from the Vietnamese mushroom Ganoderma colossum. J Nat Prod 2008;71:1022-6.

89. Cassels BK, Asencio M. Anti-HIV activity of natural triterpenoids and hemisynthetic derivatives 2004-2009. Phytochem Rev 2011;10:545-64.

90. Leber MF, Efferth T. Molecular principles of cancer invasion and metastasis (review). Int J Oncol 2009;34:881-95.

91. Chen NH, Liu JW, Zhong JJ. Ganoderic acid me inhibits tumor invasion through down-regulating matrix metalloproteinases 2/9 gene 
expression. J Pharmacol Sci 2008;108:212-6.

92. Bielawski K, Bielawska A, Słodownik T, Bołkun-Skórnicka U, Muszyńska A. Proline-linked nitrosoureas as prolidase-convertible prodrugs in human breast cancer cells. Pharmacol Rep 2008;60:171-82.

93. Moss LA, Jensen-Taubman S, Stetler-Stevenson WG. Matrix metalloproteinases: Changing roles in tumor progression and metastasis. Am J Pathol 2012;181:1895-9.

94. Chen NH, Zhong JJ. P53 is important for the anti-invasion of ganoderic acid T in human carcinoma cells. Phytomedicine 2011;18:719-25.

95. Cheng CR, Yue QX, Wu ZY, Song XY, Tao SJ, Wu XH, et al. Cytotoxic triterpenoids from Ganoderma lucidum. Phytochemistry 2010; 71:1579-85.

96. Brown NS, Jones A, Fujiyama C, Harris AL, Bicknell R. Thymidine phosphorylase induces carcinoma cell oxidative stress and promotes secretion of angiogenic factors. Cancer Res 2000;60:6298-302.

97. Bendre MS, Gaddy-Kurten D, Mon-Foote T, Akel NS, Skinner RA, Nicholas RW, et al. Expression of interleukin 8 and not parathyroid hormone-related protein by human breast cancer cells correlates with bone metastasis in vivo. Cancer Res 2002;62:5571-9.

98. Freund A, Chauveau C, Brouillet JP, Lucas A, Lacroix M, Licznar A, et al. IL-8 expression and its possible relationship with estrogen-receptornegative status of breast cancer cells. Oncogene 2003;22:256-65.

99. Thyagarajan A, Jiang J, Hopf A, Adamec J, Sliva D. Inhibition of oxidative stress-induced invasiveness of cancer cells by Ganoderma lucidum is mediated through the suppression of interleukin-8 secretion. Int J Mol Med 2006;18:657-64.

100. Kohda H, Tokumoto W, Sakamoto K, Fujii M, Hirai Y, Yamasaki K, et al. The biologically active constituents of Ganoderma lucidum (Fr.) karst. Histamine release-inhibitory triterpenes. Chem Pharm Bull (Tokyo) 1985;33:1367-74.

101. Su CH, Lai MN, Chan MH. Hepato-protective triterpenoids from Ganoderma tsugae Murrill. In: Mushroom Biology and Mushroom Products. Hong Kong, China: The Chinese University Press; 1993. p. 275-83.

102. Chen RY, Yu DQ. Studies on the triterpenoid constituents of the spores from Ganoderma lucidum Karst. J Chin Pharm Sci 1993;2:91-6.

103. Liu LY, Chen H, Liu C, Wang HQ, Kang J, Li Y, et al. Triterpenoids of Ganoderma theaecolum and their hepatoprotective activities. Fitoterapia 2014;98:254-9.

104. Wu H, Tang S, Huang Z, Zhou Q, Zhang P, Chen Z, et al. Hepatoprotective effects and mechanisms of action of triterpenoids from lingzhi or reishi medicinal mushroom Ganoderma lucidum (Agaricomycetes) on $\alpha$-amanitin-induced liver injury in mice. Int $\mathrm{J}$ Med Mushrooms 2016;18:841-50.

105. Wu JG, Kan YJ, Wu YB, Yi J, Chen TQ, Wu JZ, et al. Hepatoprotective effect of Ganoderma triterpenoids against oxidative damage induced by tert-butyl hydroperoxide in human hepatic hepG2 cells. Pharm Biol 2016;54:919-29.

106. Sudheesh NP, Ajith TA, Mathew J, Nima N, Janardhanan KK. Ganoderma lucidum protects liver mitochondrial oxidative stress and improves the activity of electron transport chain in carbon tetrachloride intoxicated rats. Hepatol Res 2012;42:181-91.

107. Fujita A, Arisawa M, Saga M, Hayashi T, Morita N. Two new lanostanoids from Ganoderma lucidum. J Nat Prod 1986;49:1122-5.

108. Lai CS, Yu MS, Yuen WH, So KF, Zee SY, Chang RC. Antagonizing $\beta$-amyloid peptide neurotoxicity of the anti-aging fungus Ganoderma lucidum. Brain Res 2008;1190:215-24.

109. Zhou Y, Qu ZQ, Zeng YS, Lin YK, Li Y, Chung P, et al. Neuroprotective effect of preadministration with Ganoderma lucidum spore on rat hippocampus. Exp Toxicol Pathol 2012;64:673-80.

110. Kubota T, Asaka Y, Miura I, Mori H. Structures of ganoderic acid A and B, two new lanostane type bitter triterpenes from Ganoderma lucidum (FR.) KARST. Helv Chim Acta 1982;65:611-9.

111. Lin LJ, Shiao MS, Yeh SF. Triterpenes from Ganoderma lucidum. Phytochemistry 1988;27:2269-71.

112. Zhang XQ, Ip FC, Zhang DM, Chen LX, Zhang W, Li YL, et al. Triterpenoids with neurotrophic activity from Ganoderma lucidum. Nat Prod Res 2011;25:1607-13.

113. González AG, León F, Rivera A, Muñoz CM, Bermejo J. Lanostanoid triterpenes from Ganoderma lucidum. J Nat Prod 1999;62:1700-1.

114. Lee I, Ahn B, Choi J, Hattori M, Min B, Bae K, et al. Selective cholinesterase inhibition by lanostane triterpenes from fruiting bodies of Ganoderma lucidum. Bioorg Med Chem Lett 2011;21:6603-7.

115. De Marzo AM, Platz EA, Sutcliffe S, Xu J, Grönberg H, Nelson WG, et al. Inflammation in prostate carcinogenesis. Nat Rev Cancer 2007; 7:256-69.

116. Birbach A, Eisenbarth D, Kozakowski N, Ladenhauf E, Schmidt-
Supprian M, Schmid JA, et al. Persistent inflammation leads to proliferative neoplasia and loss of smooth muscle cells in a prostate tumor model. Neoplasia 2011;13:692-703.

117. Lin CY, Lin CJ, Chen KH, Wu JC, Huang SH, Wang SM, et al. Macrophage activation increases the invasive properties of hepatoma cells by destabilization of the adherens junction. FEBS Lett 2006;580:3042-50

118. Kimura YN, Watari K, Fotovati A, Hosoi F, Yasumoto K, Izumi H, et al. Inflammatory stimuli from macrophages and cancer cells synergistically promote tumor growth and angiogenesis. Cancer Sci 2007;98:2009-18.

119. Dudhgaonkar S, Thyagarajan A, Sliva D. Suppression of the inflammatory response by triterpenes isolated from the mushroom Ganoderma lucidum. Int Immunopharmacol 2009;9:1272-80.

120. Hirotani M, Ino C, Furuya T, Shiro M. Ganoderic acids T, S and R, new triterpenoids from the cultured mycelia of Ganoderma lucidum. Chem Pharm Bull 1986;234:2282-5.

121. Xu K, Liang X, Gao F, Zhong J, Liu J. Antimetastatic effect of ganoderic acid $\mathrm{T}$ in vitro through inhibition of cancer cell invasion. Process Biochem 2010;45:1261-7.

122. Komoda Y, Nakamura H, Ishihara S, Uchida M, Kohda H, Yamasaki K. Structures of new terpenoid constituents of Ganoderma lucidum (Fr.) Karst (Polyporaceae). Chem Pharm Bull 1985;33:4829-35.

123. Jiang J, Grieb B, Thyagarajan A, Sliva D. Ganoderic acids suppress growth and invasive behavior of breast cancer cells by modulating AP-1 and NF-kappaB signaling. Int J Mol Med 2008;21:577-84.

124. Nishitoba T, Sato H, Shirasu S, Sakamura S. Novel triterpenoids from the mycelial mat at the previous stage of fruiting of Ganoderma lucidum. Agric Biol Chem 1987;51:619-22.

125. Chen NH, Zhong JJ. Ganoderic acid Me induces G1 arrest in wild-type p53 human tumor cells while G1/S transition arrest in p53-null cells. Process Biochem 2009;44:928-33.

126. Jiang Z, Jin T, Gao F, Liu J, Zhong J, Zhao H. Effects of ganoderic acid $\mathrm{Me}$ on inhibiting multidrug resistance and inducing apoptosis in multidrug resistant colon cancer cells. Process Biochem 2011;46: 1307-14.

127. Zhou L, Shi P, Chen NH, Zhong JJ. Ganoderic acid me induces apoptosis through mitochondria dysfunctions in human colon carcinoma cells. Process Biochem 2011;46:219-25.

128. Li F, Wang Y, Wang X, Li J, Cui H, Niu M, et al. Ganoderic acids suppress growth and angiogenesis by modulating the NF- $\mathrm{BB}$ signaling pathway in breast cancer cells. Int J Clin Pharmacol Ther 2012;50: 712-21

129. Li P, Deng YP, Wei XX, Xu JH. Triterpenoids from Ganoderma lucidum and their cytotoxic activities. Nat Prod Res 2013;27:17-22.

130. Li YB, Liu RM, Zhong JJ. A new ganoderic acid from Ganoderma lucidum mycelia and its stability. Fitoterapia 2013;84:115-22.

131. Nishitoba T, Sato H, Sakamura S. Novel mycelial components, ganoderic acid $\mathrm{Mg}, \mathrm{Mh}, \mathrm{Mi}, \mathrm{Mj}$ and $\mathrm{Mk}$, from the fungus Ganoderma lucidum. Agric Biol Chem 1987;51:1149-53.

132. Chen SY, Chang CL, Chen TH, Chang YW, Lin SB. Colossolactone H, a new Ganoderma triterpenoid exhibits cytotoxicity and potentiates drug efficacy of gefitinib in lung cancer. Fitoterapia 2016;114:81-91.

133. Chen S, Li X, Yong T, Wang Z, Su J, Jiao C, et al. Cytotoxic lanostanetype triterpenoids from the fruiting bodies of Ganoderma lucidum and their structure-activity relationships. Oncotarget 2017;8:10071-84.

134. Jiang J, Jedinak A, Sliva D. Ganodermanontriol (GDNT) exerts its effect on growth and invasiveness of breast cancer cells through the down-regulation of CDC20 and uPA. Biochem Biophys Res Commun 2011;415:325-9.

135. Shiao MS. Triterpenoid natural products in the fungus Ganoderma lucidum. J Chin Chem Soc 1992;39:669-74.

136. Hajjaj H, Macé C, Roberts M, Niederberger P, Fay LB. Effect of 26-oxygenosterols from Ganoderma lucidum and their activity as cholesterol synthesis inhibitors. Appl Environ Microbiol 2005; $71: 3653-8$.

137. Niedermeyer TH, Lindequist U, Mentel R, Gördes D, Schmidt E, Thurow K, et al. Antiviral terpenoid constituents of Ganoderma pfeifferi. J Nat Prod 2005;68:1728-31.

138. Nishitoba T, Oda K, Sato H, Sakamura S. Novel triterpenoids from the fungus Ganoderma lucidum. Agric Biol Chem 1988;52:367-72.

139. Ma BJ, Zhou Y, Ruan Y, Ma JC, Ren W, Wen CN. Lanostane-type triterpenes from the sporoderm-broken spores of Ganoderma lucidum. J Antibiot 2012;65:165-7.

140. Lin CN, Fann YF, Chung MI. Steroids of formosan Ganoderma tsugae. Phytochemistry 1997;46:1143-6.

141. Weng CJ, Chau CF, Hsieh YS, Yang SF, Yen GC. Lucidenic acid inhibits PMA-induced invasion of human hepatoma cells through inactivating 
MAPK/ERK signal transduction pathway and reducing binding activities of NF-kappaB and AP-1. Carcinogenesis 2008;29:147-56.

142. Hsu CL, Yu YS, Yen GC. Lucidenic acid B induces apoptosis in human leukemia cells via a mitochondria-mediated pathway. J Agric Food Chem 2008;56:3973-80.

143. Nishitoba T, Sato H, Kasai T, Kawagishi H, Sakamura S. New bitter $\mathrm{C} 27$ and C30 terpenoids from the fungus Ganoderma lucidum (Reishi). Agric Biol Chem 1985;49:1793-8.

144. Weng CJ, Chau CF, Chen KD, Chen DH, Yen GC. The anti-invasive effect of lucidenic acids isolated from a new Ganoderma lucidum strain. Mol Nutr Food Res 2007;51:1472-7.

145. Kinge TR, Mih AM. Secondary metabolites of oil palm isolate of Ganoderma zonatum Murrill from Cameroon and their cytotoxicity against five human tumor cell lines. Afr J Biotechnol 2011;10:8440-7.

146. Chairul SM, Hayashi Y. Lanostanoid triterpenes from Ganoderma applanatum. Phytochemistry 1994;35:1305-8.

147. Leon F, Valencia M, Rivera A, Nieto I, Quintana J, Estevez F et al. Novel cytostatic lanostanoid triterpenes from Ganoderma australe. Helv Chim Acta 2003;86:3088-95.
148. Kleinwächter P, Anh N, Kiet TT, Schlegel B, Dahse HM, Härtl A, et al. Colossolactone, new triterpenoid metabolites from a Vietnamese mushroom Ganoderma colossum. J Nat Prod 2001;64:236-9.

149. Kikuchi T, Kanomi S, Murai Y, Kadota S, Tsubono K, Ogita ZI Constituents of the fungus Ganoderma lucidum (FR.) KARST. III. Structures of ganolucidic acids A and B, new lanostane-type triterpenoids. Chem Pharm Bull 1986;34:4030-6.

150. Lee I, Kim H, Youn U, Kim J, Min B, Jung H, et al. Effect of lanostane triterpenes from the fruiting bodies of Ganoderma lucidum on adipocyte differentiation in 3T3-L1 cells. Planta Med 2010;76:1558-63.

151. Mothana RA, Ali NA, Jansen R, Wegner U, Mentel R, Lindequist U, et al. Antiviral lanostanoid triterpenes from the fungus Ganoderma pfeifferi. Fitoterapia 2003;74:177-80.

152. Arisawa M, Fujita A, Saga M, Fukumura H, Hayashi T, Shimizu M, et al. Three new lanostanoids from Ganoderma lucidum. J Nat Prod 1986;49:621-5.

153. Johnson BM, Doonan BP, Radwan FF, Haque A. Ganoderic acid DM: An alternative agent for the treatment of advanced prostate cancer. Open Prost Cancer J 2010;3:78-85. 